\title{
Using a particle packing model considering cement as part of the "dry arrangement"
}

\author{
Utilização de um modelo de empacotamento de \\ partículas considerando o cimento como parte \\ do "arranjo seco"
}

\author{
Aline Hermann ${ }^{1}$, Géssica Katalyne Bilcati ${ }^{2}$, Isabela Ames ${ }^{2}$, \\ Ana Gabriella Chekalski da Silva ${ }^{2}$, Daniel Dal Agnol Grossman ${ }^{2}$, \\ Thayna Brena Alves Fausto ${ }^{2}$
}

\footnotetext{
${ }^{1}$ Serviço Social Autônomo PARANÁEDUCAÇÃO, CEP: 85010-100, Guarapuava, Paraná, Brasil.

${ }^{2}$ Departamento de Engenharia Civil - UTFPR, CEP: 85053-525, Guarapuava, Paraná, Brasil. e-mail: enge.aline@hotmail.com, gekatalyne@gmail.com, isabela.ames@hotmail.com, anagabriellasilva@outlook.com, danieldgrossmann@gmail.com, thaayna.brena@gmail.com.
}

\section{RESUMO}

O "arranjo seco" de um composto cimentício pode ser definido como a relação mássica ou volumétrica entre os materiais secos que o constitui. Por meio da fixação da espécie de material componente deste arranjo e do processo de produção do composto cimentício, é possível analisar de forma mais clara o processo de dosagem de um composto cimentício qualquer. Para analisar o comportamento destes compostos pelas mudanças nas quantidades volumétricas dos seus componentes, tem-se os modelos básicos de empacotamento de partículas, como é o caso do Modelo de Empacotamento de Funk e Dinger. O presente artigo tem como finalidade analisar as propriedades no estado fresco (índice de consistência) e endurecido (absorção de água, massa específica e resistência à compressão axial) das argamassas produzidas a partir do modelo de empacotamento de partículas de Funk e Dinger. Neste modelo, as partículas de cimento foram consideradas como parte do "arranjo seco" (agregados), transformando em "matriz" (ou agente de separação) somente o volume de água, facilitando desta forma a definição do consumo de cimento. Os resultados demonstraram que é possível alcançar, pela alteração da quantidade volumétrica dos componentes, uma redução do consumo de cimento de aproximadamente $32 \%$ e ao mesmo tempo alcançar um aumento da resistência à compressão axial de aproximadamente 59\%, juntamente com a redução da absorção e o aumento da massa especifica dos corpos de prova. Contudo, foi verificado um decréscimo significativo na trabalhabilidade das argamassas produzidas.

Palavras-chave: Modelo de empacotamento de Funk e Dinger; Cimento Portland; Agregados; Argamassa.

\section{ABSTRACT}

The "dry arrangement" of a cementitious compound can be defined as the mass or volumetric relationship between the dry materials that constitute it. By fixing the kind of material that makes up this arrangement and the cement compound production process, it is possible to more clearly analyze the dosage process of any cement compound. To analyze the behavior of these compounds in regard to the changes in volumetric quantities of their components, it is known the basic particle packing models, such as Funk and Dinger Particle Packing Model. The present article aims to analyze the properties in fresh (consistency index) and hardened state (water absorption, specific mass and axial compressive strength) of mortars produced with the Funk and Dinger Particle Packing Model. In this model, the cement particles were considered as part of the "dry arrangement" (aggregates), assuming only the water volume as the "matrix" (or separation agent), thus simplifying the definition of cement consumption. Results demonstrated that it is possible to achieve, by changing the volumetric quantity of the components, a reduction in cement consumption of approximately $32 \%$ and at the same time achieve an increase in axial compressive strength of approximately $59 \%$, a reduction in absorption and an increase in the specific mass of the specimens. However, a significant decrease in the worka- 
bility of the produced mortars was verified.

Keywords: Funk and Dinger Packing Model; Portland cement; Aggregates; Mortar.

\section{INTRODUCTION}

Mortars are cementitious compounds characterized according to predefined properties that must meet performance and durability requirements, depending on their use in civil construction, according to the current standard [1]. Moreover, cementitious materials have numerous characteristics that may influence their performance and durability, as their behavior is directly associated with dosage, type of component material, and production process used [2].

The concept of particle packing is based on the adequate proportioning of certain particle sizes, aiming to achieve compact mixtures with control of their density. In other words, when using fractions of particles of different sizes, where the smaller particles fill the voids generated between the larger ones, successively to smaller sizes, a system can be generated where these voids are significantly reduced, increasing the mixture density $[3,4]$. Thus, the behavior of mortars and concretes depends on its components characteristics and partly on their interactions [4].

Within the concept of particle packing, a mortar mixture, for example, can be understood as a "dry arrangement" of aggregate particles, whose voids are filled with cement paste or "matrix". As this matrix is more expensive and usually less resistant and durable than a natural rock, the basic dosing strategy is to achieve a granular mixture with a minimum porosity between aggregates [5], thus leaving few voids to be filled with the matrix, resulting in a lower absorption in hardened state and theoretically in a lower workability in fresh state.

For mortars, two different separation possibilities can be considered between the "dry arrangement" and the "matrix": the first one considers separation matrix as the paste (cement and water) and particles as the small aggregates; and the second considers separation matrix to be water and particles to be small aggregates (like natural or industrial sand), cement and mineral additions. The first option is the researchers' most accepted and used analysis, and one of their justifications is that cement paste (water + cement) would be responsible for controlling the cementitious compound flowability, by dispersing and lubricating aggregate particles.

Thus, the matrix must be more than sufficient to fill the voids between aggregate particles, and this means that it must exist excess matrix to obtain a thin layer of paste surrounding each particle to lubricate the mixture [6]. With low matrix content, the contact between particles will predominate (these are called stable mixtures), making the compaction difficult. With high matrix content, the contact between the particles decreases and the flowability is determined by the matrix viscosity (called fluid mixtures), facilitating the compaction [7]. By turning only water volume and not cement paste into a "matrix", water is the factor that will control the paste flowability.

Figure 1 shows the volume occupied by stable particles (a) and particles in fluid mixtures (b) in which the matrix is represented by water.

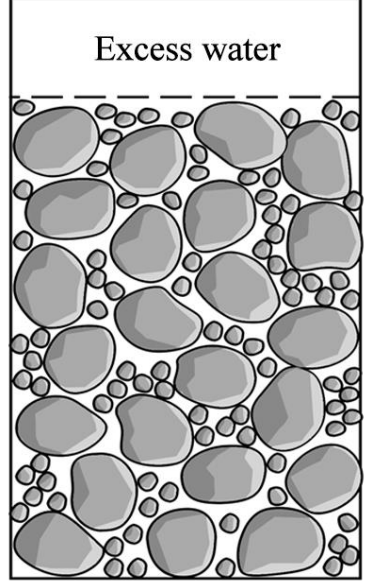

(a)

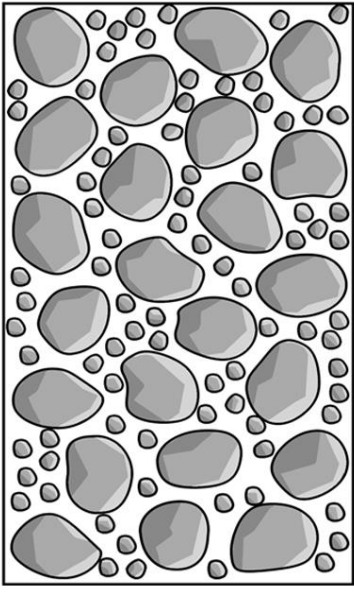

(b)

Figure 1: Volume occupied by stable particles (a) and particles in fluid mixtures (b) [8]. 
For the elaboration of the "dry arrangement" proportioning it can be used Funk and Dinger Particle Packing Model. This model is an improvement on Furnas (1929) and Andreasen and Andersen (1930) models, and shows that, in reality, both are two distinct ways of expressing the same result [9].

The purpose of Funk and Dinger model was to introduce the concept of minimum particle size into the Andreasen and Andersen equation, and to mathematically review Furnas model. After comparative analysis between these two models, Funk and Dinger proved in 1980 that, mathematically, the equations of the two models converge to Equation 1 [7].

$$
C P F T=100 \cdot \frac{D_{P}^{q}-D_{S}^{q}}{D_{L}^{q}-D_{S}^{q}}
$$

Where:

$\mathrm{CPFT}=$ accumulated percentage of particles smaller than size D;

$\mathrm{D}_{\mathrm{P}}=$ particle diameter;

$\mathrm{D}_{\mathrm{L}}=$ diameter of the system largest particle;

$\mathrm{D}_{\mathrm{S}}=$ diameter of the system smallest particle;

$q=$ distribution coefficient.

Funk and Dinger equation is a particle packing model suitable for real (practical) systems [10] once its equation deals with a low number of variables, as it only works the particle size composition of the mixture. More elaborate models with a greater number of variables have also been developed, but Funk and Dinger model can still be considered as the simplest model to be applied to concrete and mortar.

Through computational simulations, Funk and Dinger determined that to maximize packing, the value of the distribution coefficient (q) should be 0.37 [11,12]. However, this value is quite questionable regarding the representation of the optimal packing, since the concept of optimization must be correlated with compaction energy.

In general, the lower the "q" value, the lower the ratio between large and small aggregates and the greater the amount of paste to fill the voids between particles [13-15]. Thus, it is possible to state that the distribution coefficient is related to concrete and mortar workability [15].

Similarly, OLIVEIRA [7] also states that " $q$ " values smaller than 0.37 increase the flowability of concretes by allowing the existence of a greater distance between aggregate particles, increasing the amount of matrix. On the other hand, distribution coefficients smaller than 0.2 may decrease flowability due to excessive increase in the specific surface of the system. In other words, the volume of smaller particles exceeds the void index between larger particles [7].

BROUWERS and RADIX [16], and HUNGER and BROUWERS [17] recommend a " $q$ " between 0.22 and 0.25 for self-compacting concretes. However, OLIVEIRA et. al. [04] use, in their studies on selfcompacting concrete, distribution coefficients "q" equal to 0.29. Also, WANG et. al. [18] recommend a "q" between 0.23 and 0.29 for the same type of concretes. For dry concretes, Schmidt and Stutech apud HÜSKEN and BROUWERS [14] recommend " $q$ " values between 0.35 and 0.4 .

Particle packing mathematical models of simple calculation can facilitate, enhance and even lower the costs of mass production of cementitious compounds. A numerical parameter that can, at the same time, optimize packing degree and cement consumption and still serve as a flow control parameter is desirable, as it can be a simple and practical way to develop the compositions between mortar and concrete components.

Applying cement as part of the "dry arrangement" in a particle packing model can facilitate the determination of optimal cement consumption, mainly because the fine content (particles $<150 \mathrm{~mm}$ ) have a significant impact on the properties of cementitious compounds as well as on the packing degree of cement mixtures [15].

Thus, this work aims to analyze the behavior of mortars dosed from a particle packing model, with cement particles being considered as part of the "dry arrangement", assuming as the "matrix" only the volume of water. It is intended to analyze the results of each mixture, in relation to their cement consumption, fines content percentage, paste (cement + water) percentage and the particles surface area, contrasting this with the results of consistency index (admitting the results of the Flow Table test) in fresh state, and specific mass, water absorption and axial compressive strength on hardened state. 


\section{MATERIALS AND METHODS}

\subsection{Materials}

As binder it was used cement CPII-F-32, with specific mass equal to $3.11 \mathrm{~g} / \mathrm{cm}^{3}$. The reason for this choice is related to the continuity of this cement granulometry in relation to the aggregate used. This is because Funk and Dinger Particle Packing Model requires a particle size regularity for its numerical application. To obtain the cumulative percentage of particles smaller than size D (CPFT), the smaller particle diameter must always be half the larger particle size. Thus, in order to include cement as a particle in the calculation of this model, it is necessary to have a particle size of approximately half the size of the smallest aggregate particle used $(0.075 \mathrm{~mm})$.

Results obtained by AGUIAR test [19] (as shown in Figure 2) showed that $90 \%$ of CPII-F-32 cement particles are smaller than $0.04594 \mathrm{~mm}$ and $10 \%$ of particles are smaller than $0.00319 \mathrm{~mm}$. These fractions are appropriate to make the cement particle size distribution as continuous as possible in relation to the aggregate particle size distribution. This would be more difficult with a finer cement such as CP V ARI, for example.

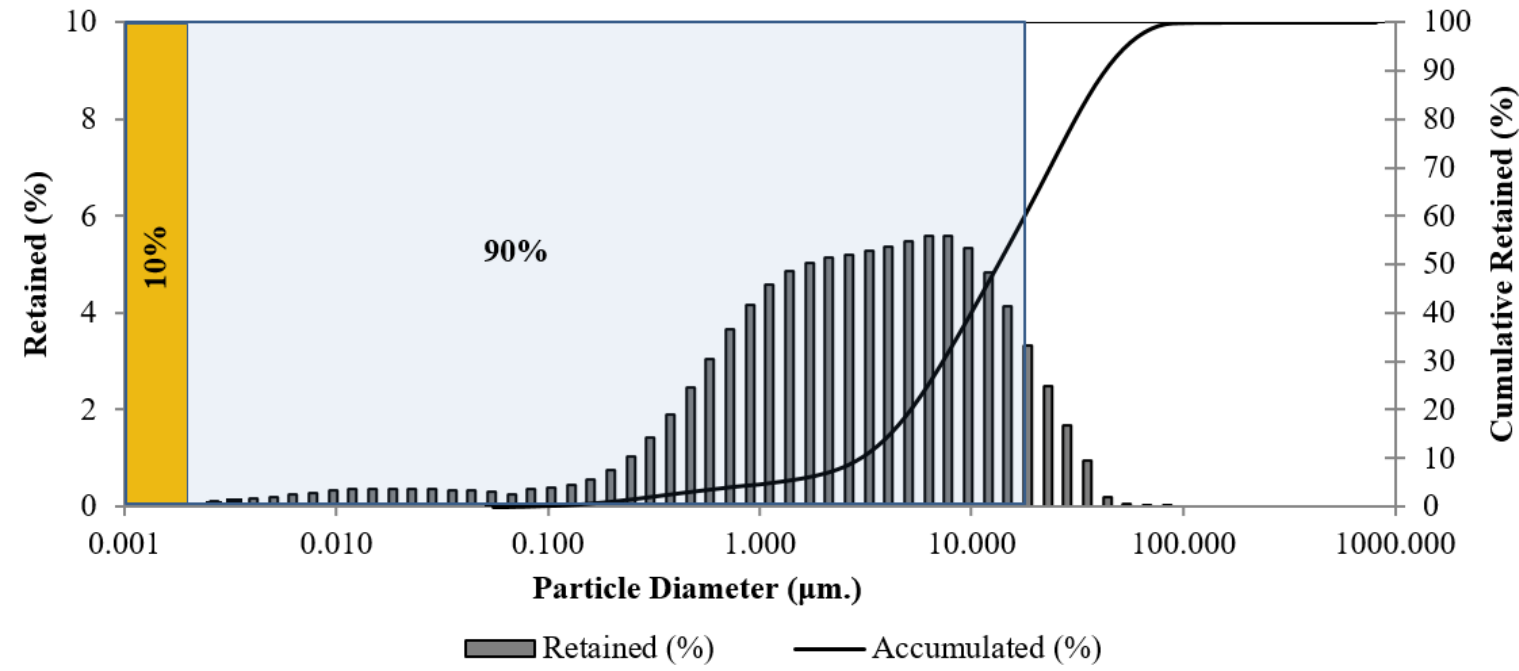

Figure 2: Laser Cement Granulometry CPII-F-32 [19]

Thus, due to the impossibility of its experimental subdivision, the particle size distribution of CP II-F32 cement was considered continuous. To include the cement in packing calculation, it was subdivided into particle size ranges of $0.038 \mathrm{~mm}, 0.019 \mathrm{~mm}, 0.009 \mathrm{~mm}, 0.005 \mathrm{~mm}$ and $0.002 \mathrm{~mm}$, which were later added to obtain the total amount of cement to be used in each mixture.

For the preparation of mortar mixtures produced by Funk and Dinger Packing Model, the aggregate employed was industrial sand, with a specific mass equal to $2.941 \mathrm{~g} / \mathrm{cm}^{3}$, obtained according to NBR NM 52 [20] with the aid of a Specific Gravity Flask (Chapman). Its use is mainly due to its more continuous particle size distribution when compared to a natural sand, a factor that optimized the sand screening process and the obtainment of the desired particle size fractions.

For this study, the normal series particle size ranges $(2.4 \mathrm{~mm}, 1.2 \mathrm{~mm}, 0.6 \mathrm{~mm}, 0.3 \mathrm{~mm}, 0.15 \mathrm{~mm}$ and $0.075 \mathrm{~mm}$ ) were adopted, and the fractions were obtained through mechanical screening, according to the tests standardized by NBR NM 248 [21] and NBR NM 46 [22]. Thus, it was respected the prescriptions of the packing model by assuring that the diameter of the particle of smaller size would be half the size of the particle of larger size.

Aggregates may generally have uniform, continuous or discontinuous particle size distributions. Uniform particle size distribution occurs when all particles belong to only one particle size range; continuous particle size distribution occurs when particle size increases continuously and proportionally; and discontinuous particle size distribution occurs when a certain particle size is absent [9]. In general, a continuous particle size distribution tends to have a better packing index than uniform and discontinuous distributions [23], since they present proportional quantities between aggregate fractions.

Another factor that corroborates the improvement in particle packing is the increased particles disper- 
sion [9], either through compacting, vibration, vibrocompaction or even through the use of plasticizers or superplasticizers.

Chemical additives, whether plasticizers or superplasticizers, help to reduce porosity, improving the durability of concrete [24], since reducing friction between particles makes them more easily dispersed, further improving the mixture density. After all, it is known that for application, a concrete mixture needs much more water than needed for cement hydration, which results in porosity in hardened concrete, reducing the potential of its mechanical properties and facilitating degradation of this material [9].

The incorporation of plasticizing additives acts positively in the production of high packing mortars, once it promotes greater fluidity without increasing the water/cement ratio. They also act to reduce the formation of fine agglomerates, which tends to create regions of high porosity in mortars.

In order to reduce the interference of fines agglomeration on the packing of the produced mortars, a chloride-free concentrated plasticizing additive was used, whose basic composition is obtained from natural resins. Its density is $1.03 \mathrm{~g} / \mathrm{cm}^{3}$.

\subsection{Methods}

First, the cumulative percentage of particles smaller than "D" (CPFT) was calculated using Funk and Dinger packing model, according to the Equation 1, with the $4.8 \mathrm{~mm}$ diameter being used as the largest particle diameter $\left(\mathrm{D}_{\mathrm{L}}\right)$ and the diameter of $0.002 \mathrm{~mm}$ as the smallest particle $\left(\mathrm{D}_{\mathrm{S}}\right)$. It also was used the distribution coefficient $(\mathrm{q})$ ranging from 0.1 to 0.6 , with $\mathrm{q}=0.6$ being the maximum value adopted due to previous practical experiments that had shown that mixtures produced with distribution coefficient (q) between 0.7 and 1.0 lead to the obtainment of extremely dry mortars, situation that could cause difficulties at fixing the water/cement ratio.

Then, the volume retained in each sieve $(4.800 \mathrm{~mm}, 2.400 \mathrm{~mm}, 1.200 \mathrm{~mm}, 0.600 \mathrm{~mm}, 0.300 \mathrm{~mm}$, $0.150 \mathrm{~mm}, 0.075 \mathrm{~mm}, 0.038 \mathrm{~mm}, 0.019 \mathrm{~mm}, 0.009 \mathrm{~mm}, 0.005 \mathrm{~mm}$ and $0.002 \mathrm{~mm}$ ) was calculated by the difference between the volume that had passed through the previous sieve $\left(\mathrm{D}_{\mathrm{P}+1}\right)$ and the volume that had passed through the sieve under analysis $\left(\mathrm{D}_{\mathrm{P}}\right)$. It was considered a single retained volume in relation to cement, as the total cement volume corresponds to the sum of the retained volumes in the range from $0.038 \mathrm{~mm}$ to $0.002 \mathrm{~mm}$, once it is not feasible the separation of cement particles into size fractions.

The amount of plasticizing additive used was $0.2 \%$ in relation to the total amount of fines content (cement + sand fraction between $0.150 \mathrm{~mm}$ and $0.075 \mathrm{~mm}$ ), according to the manufacturer's recommendations and also taking into account the agglomeration of particles with a smaller diameter than $0.150 \mathrm{~mm}$.

Subsequently, the mixture design in relation to the cement volume was calculated by taking the retained volume in each particle range and dividing by the cement volume. The mass ratio of the mixture design was obtained by multiplying the volume of each fraction by the aggregate specific mass, dividing by the volume of cement and multiplying by cement specific mass. Table 1 presents the mass ratio of the mixture designs calculated for each distribution coefficient, and presents some characteristics of each mixture design such as cement consumption, fines percentage, paste percentage, water consumption, fineness modulus and particle surface area.

Table 1: Mass ratio of mixtures for each distribution coefficient (q) and its characteristics

\begin{tabular}{|c|c|c|c|c|c|c|c|}
\hline \multirow{3}{*}{\multicolumn{2}{|c|}{ FRACTIONS }} & \multicolumn{6}{|c|}{ MASS RATIO OF MIXTURES } \\
\hline & & \multicolumn{6}{|c|}{ Q (DISTRIBUTION COEFFICIENT) } \\
\hline & & 0.1 & 0.2 & 0.3 & 0.4 & 0.5 & 0.6 \\
\hline \multirow{6}{*}{ Industrial sand } & $4.800<\mathrm{g}<2.400$ & 0.3 & 0.6 & 1.0 & 1.6 & 2.7 & 4.5 \\
\hline & $2.400<\mathrm{g}<1.200$ & 0.3 & 0.5 & 0.8 & 1.2 & 1.9 & 2.9 \\
\hline & $1.200<\mathrm{g}<0.600$ & 0.3 & 0.4 & 0.6 & 0.9 & 1.3 & 1.9 \\
\hline & $0.600<\mathrm{g}<0.300$ & 0.3 & 0.4 & 0.5 & 0.7 & 1.0 & 1.3 \\
\hline & $0.300<\mathrm{g}<0.150$ & 0.2 & 0.3 & 0.4 & 0.5 & 0.7 & 0.8 \\
\hline & $0.150<\mathrm{g}<0.075$ & 0.2 & 0.3 & 0.3 & 0.4 & 0.5 & 0.6 \\
\hline Cement & $0.075<\mathrm{g}<0.002$ & 1.0 & 1.0 & 1.0 & 1.0 & 1.0 & 1.0 \\
\hline \multicolumn{2}{|c|}{ Cement consumption $\left(\mathrm{kg} / \mathrm{m}^{3}\right)$ : } & 731 & 611 & 491 & 379 & 283 & 204 \\
\hline \multicolumn{2}{|c|}{ Fines percentage $(<0.150 \mathrm{~mm})$ : } & $46 \%$ & $37 \%$ & $29 \%$ & $22 \%$ & $16 \%$ & $12 \%$ \\
\hline
\end{tabular}




\begin{tabular}{l|c|c|c|c|c|c}
\hline Percentage of paste (cement + water): & $47 \%$ & $38 \%$ & $29 \%$ & $22 \%$ & $16 \%$ & $11 \%$ \\
\hline Water consumption $(\mathrm{g}):$ & 413.5 & 345.7 & 277.7 & 214.6 & 159.9 & 115.6 \\
\hline Fineness Modulus: & 1.61 & 1.88 & 2.12 & 2.32 & 2.48 & 2.60 \\
\hline Particles surface area $\left(\mathrm{m}^{2}\right):$ & 53.3 & 46.5 & 39.4 & 32.5 & 26.2 & 20.9 \\
\hline
\end{tabular}

It was verified that the cement consumption decreased due to the increase of the distribution coefficient, from $731 \mathrm{~kg} / \mathrm{m}^{3}$ with a distribution coefficient of 0.1 to $204 \mathrm{~kg} / \mathrm{m}^{3}$ with a distribution coefficient of 0.6 . Similarly, there was a decrease in the fines content $(<0.150 \mathrm{~mm})$ that includes, in addition to cement, percentage of fines in industrial sand, which went from $46 \%$ to $12 \%$. This fact justified the increase of particles surface area, since when there is a higher concentration of fines, there is also a larger specific area of the particles, which causes an increase in the water consumption necessary to cover the particles. Moreover, this decrease in the fines percentage in the mixture design as the distribution coefficient increases, is mainly due to the reduction of cement along the distribution coefficients. The percentage of paste was similarly reduced as the distribution coefficient increased.

To calculate cement consumption of each mixture mass ratio, the IPT/EPUSP dosing method was adopted. The percentage of incorporated air was neglected in these calculations as it is considered a small value. According to some authors this value is around 2\% [25].

The fines percentage was calculated by the ratio between mass quantities of the fraction smaller than $0.150 \mathrm{~mm}$ and the total mass of all fractions.

The percentage of paste was calculated by the ratio between the amount of the cement and water (in grams) and the total mass of all mixtures components.

The water/cement ratio was set at 0.48 for all mixtures and was adopted primarily to meet the criterion for determining the compressive strength of Portland cement, according to NBR 7215 [26]. However, it was fundamental to analyze the influence of different dosages between aggregates on mortars compressive strength, since water/cement ratio is proven to be a factor of great influence on cementitious compounds strength [27].

The particles surface area was calculated considering all particles as spherical particles of average diameter. In other words, the surface areas of all the particles needed to produce a mortar volume were summed, and their diameter was considered as the arithmetic mean of each particle size fraction.

The fineness modulus was calculated considering the sum of the retained percentages accumulated in mass of an aggregate, in the sieves of the normal series $(4.800 \mathrm{~mm}, 2.400 \mathrm{~mm}, 1.200 \mathrm{~mm}, 0.600 \mathrm{~mm}, 0.300$ $\mathrm{mm}, 0.150 \mathrm{~mm}$ ) according to the NBR NM 248 [21], divided by 100 .

Mortars were made according to the procedures described by NBR 7215 [26] with the exception that all steps were developed at low speed of the mechanical mixer, because there was an overflow of material when high speed was used. Thus, to avoid material loss, only low speed was used.

To perform the tests, six cylindrical specimens with dimensions $50 \mathrm{~mm}$ x $100 \mathrm{~mm}$ were molded. After the molding process, the specimens were sent to a humid chamber, where they remained for 24 hours. After 24 hours, the specimens were kept for 27 days completely immersed in water also inside the humid chamber, remaining there until the tests were performed.

The tests performed on the mortar specimens were, on the fresh state: the Flow Table test (consistency index) [28]; and on the hardened state: the water absorption test and specific mass absorption test at 27 and 28 days of age [29] and the axial compressive strength test [26], at 28 days of age.

\section{RESULTS AND DISCUSSION}

\subsection{Consistency index (Flow Table)}

By considering cement as a granular material in the particle size distribution, its consumption reduces as the distribution coefficient of Funk and Dinger Packing Model increases. By fixing water/cement ratio, water consumption of the mortar also decreased, which means that the percentage of paste (cement + water) decreased with the increase of the distribution coefficient, directly influencing the workability of the mortar.

The mortar consistency test (Flow Table) showed that mixture designs with distribution coefficients lower than 0.3 led to the production of more fluid mortars and that mixtures produced with distribution coef- 
ficients greater than 0.3 led to drier mortars, as shown in Figure 3.

YOUSUF et al. [30], in their studies analyzing low cement concrete produced with different distribution coefficients $(0.26,0.31$ and 0.37$)$ and with constant water/cement ratios of 0.47 and 0.61 , also found a reduction in slump test values and a density increase due to the increase in the distribution coefficient from 0.26 to 0.37 .

For $\mathrm{q}=0.1$ and $\mathrm{q}=0.2$, the two mortars were cohesive and with little exudation, providing greater fluidity to the mixture. These results are similar to those recommenended by BROUWERS and RADIX [16] and Hunger and Brouwers [17] to self-compacting concretes.

On the other hand, as the distribution coefficient increased, the percentage of water was increasingly insufficient to proceed with the Flow Table method analysis. This leads to the conclusion that mortars of this type need different compaction methods, such as vibrocompaction. Other tests such as VeBe test, intended for dry cementitious compounds could be used for a better analysis of mortars with higher distribution coefficients.

In addition, for distribution coefficients greater than 0.4 , difficulties were found regarding the molding of the specimens. In mortars with distribution coefficient equal to 0.6 , the agglutination between materials occurred unevenly.

Thus, it can be concluded that the mixture designs with distribution coefficients 0.1 and 0.2 presented a sufficient amount of free water to promote particle lubrication, while for "q" values equal to or greater than 0.3 , the amount of free water had become increasingly unable to promote proper cohesion and workability. Since, the greater the volume of excess water, the thicker the water films and the further apart the particles will be from each other, leading to less friction and interaction between the particles and, eventually, to a greater workability [31].

Particle distribution was important for mortar fluidity definition and the distribution coefficient can serve as a numerical parameter of flow control. An increase in the amount of water in certain "dry arrangements" may not imply increased paste fluidity, but increased segregation and even mortar exudation.

As also pointed out by Rizwan, et al., the fineness modulus of sand particle distribution increases with the distribution coefficient, which indicates that as the distribution coefficient increases, the sand particle distribution becomes coarser [32]. This result can be confirmed by the particles surface area of each mixture, which decreased with the increase of the distribution coefficient, since a volume of smaller particles has a larger surface area than an equal volume of larger particles. When compared to the results of the consistency index (Flow Table test), both indicate that the increase in the distribution coefficient, in addition to providing less fluidity, provides mixtures with coarser particles. 


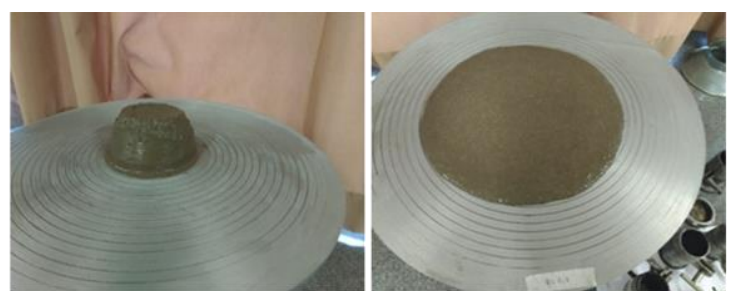

Distribution coefficient $\mathrm{q}=0.1$

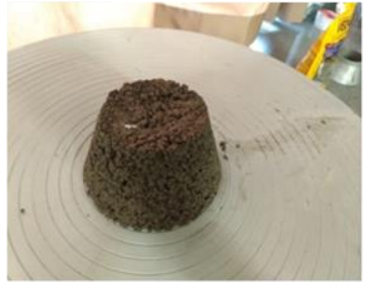

Distribution coefficient $\mathrm{q}=0.3$

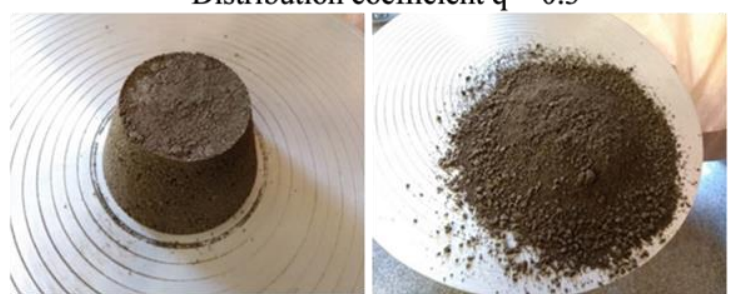

Distribution coefficient $\mathrm{q}=0.5$

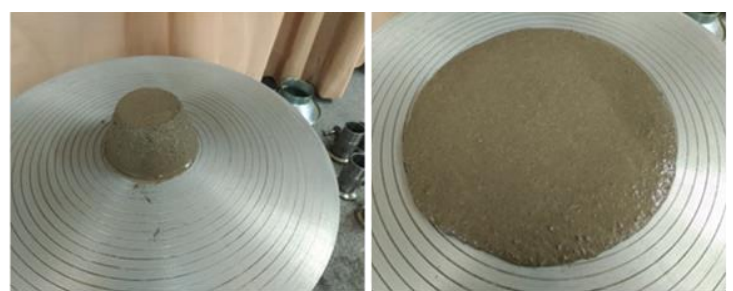

Distribution coefficient $\mathrm{q}=0.2$

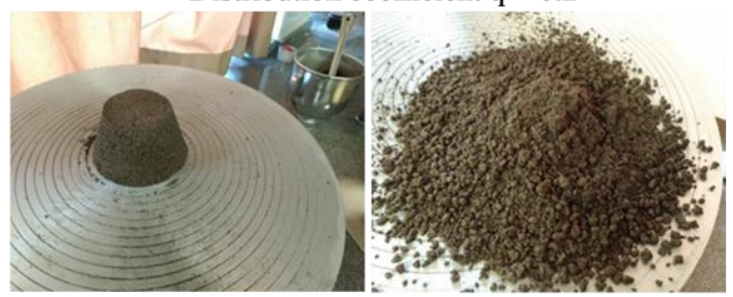

Distribution coefficient $\mathrm{q}=0.4$

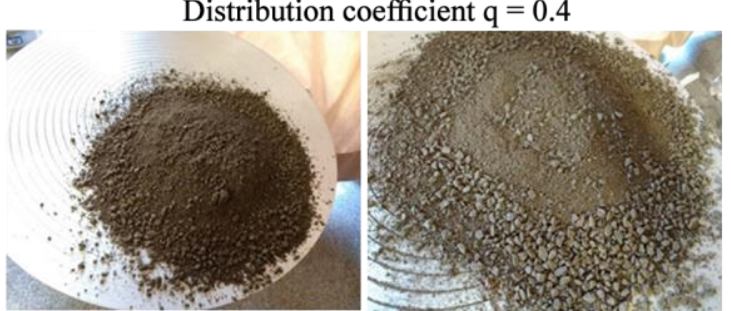

Distribution coefficient $\mathrm{q}=0.6$

Figure 3: Flow Table test for the different distribution coefficients of Funk and Dinger Packing Model

\subsection{Specific mass and absorption}

For the analysis of mortars in the hardened state, it was found experimentally that the highest value for specific mass and the lowest value for absorption was observed in the mortar with a distribution coefficient equal to 0.3. These results are statistically significant, as shown in the values in Figure 4.

Lower absorption and higher specific mass leads to a greater particle packing, since there is less porosity. The distribution coefficient found experimentally $(q=0.3)$ differs from that obtained by computer simulations $(q=0.37)$. However, it should be noted that, as already mentioned, obtaining a distribution coefficient is quite questionable regarding the representation of the optimal packing, since the concept of optimization must be correlated with the compaction energy. It is possible that the compaction energy used in this work was not sufficient to locate all the particles in the specimen in the best way, especially for the mixture designs with larger distribution coefficients, such as 0.5 and 0.6 . 


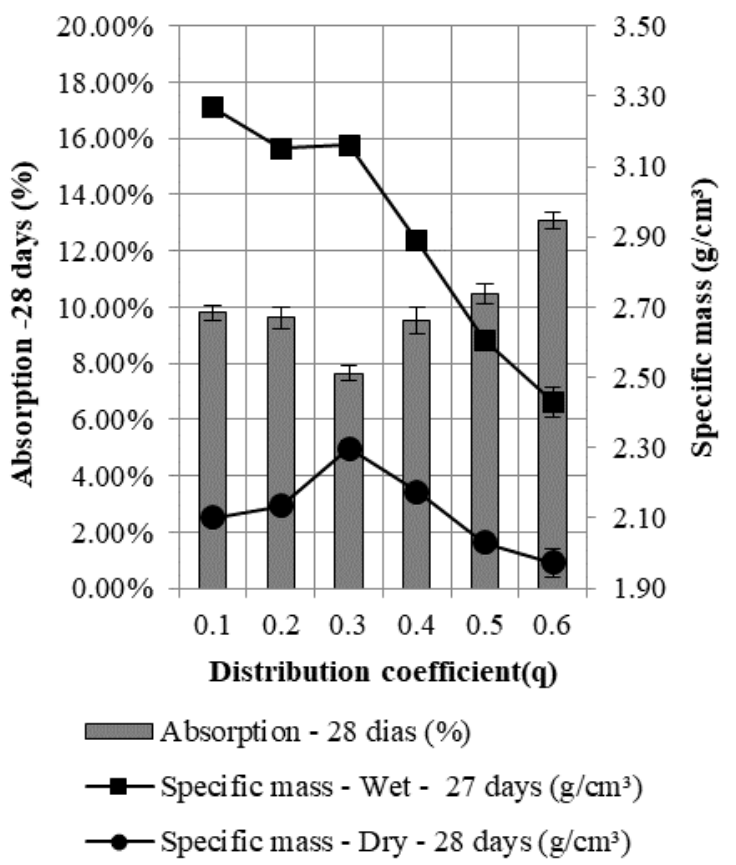

Figure 4: Specific mass and water absorption in relation to distribution coefficient

Similar results were found in Chu's study [33], where tests were carried out on compacted and uncompacted concretes according to the Standard BS 1881-107: 1983. In Chu's study, uncompacted concretes presented higher densities with an increase in the cementitious paste volume, and compacted concretes showed higher densities with the reduction of the cementitious paste volume.

However, it can be said that when the coarse/fine aggregate ratio increased (which represents an increase in the fineness modulus shown in Table 1), even though the specific mass of the combined aggregates showed a downward tendency, the percentage of voids showed an increasing tendency. The same result was also found in the literature [34].

\subsection{Axial compressive strength}

The results obtained from the compressive strength test can be analyzed in Figure 5. As for the specific mass and absorption results, the mixtures produced with a distribution coefficient equal to 0.3 were the ones that presented the highest results concerning axial compressive strength.

Results very similar to that are found in the literature where the packing density of sand mixtures increases with the distribution coefficient and the optimal packing degree occurs at the distribution coefficient of 0.35 , after which it starts decreasing, or more realistically when "q" is the range of $0.3-0.4$ [32].

For a distribution coefficient 0.3 , there was a $32.83 \%$ reduction in cement consumption compared to the highest cement consumption $\left(731 \mathrm{~kg} / \mathrm{m}^{3}\right)$ generated by the distribution coefficient 0.1 . Even so, the average axial compressive strength increased $58.70 \%$, from $27.99 \mathrm{MPa}$ (for the mixture generated by q $=0.1$ ) to $44.42 \mathrm{MPa}$ (for the mixture generated by $\mathrm{q}=0.3$ ).

Similarly, for a distribution coefficient 0.4 , even with a considerable reduction in cement consumption $(48.15 \%)$, there was no significant reduction in axial compressive strength. Thus, it was observed that, even though cement consumption decreased, the axial compressive strength was maintained, a fact that can be attributed to the better packing and dispersion of the particles, since water/cement ratio was fixed at 0.48 .

For values greater than 0.4 there was a significant decrease in the axial compressive strength of the specimens, which was mainly due to the high reduction of cement consumption. However, more effective compaction energy (on the specimens molding), could increase this strength, and this increase would be due to the increased particle packing. 


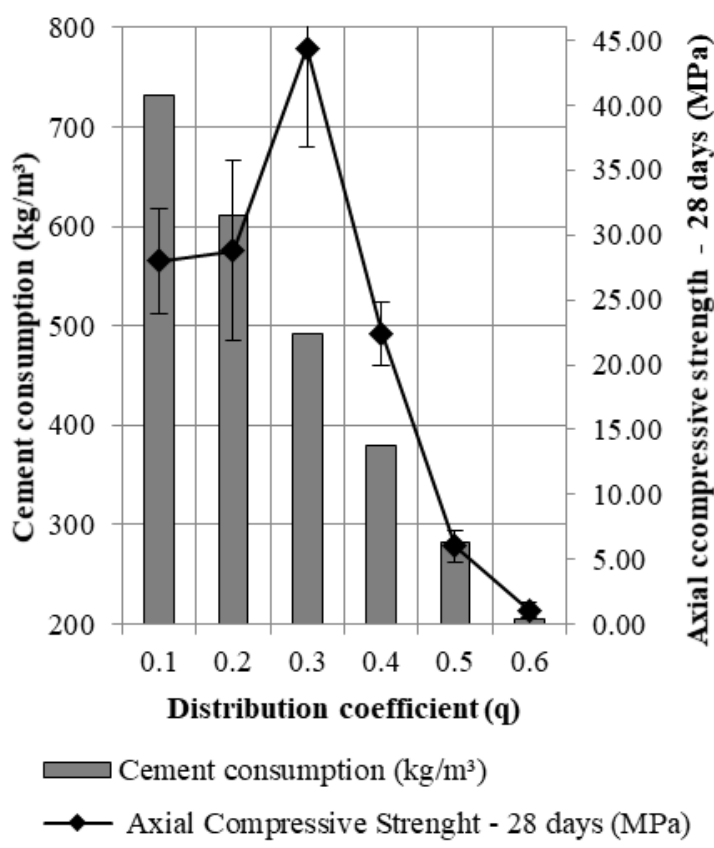

Figure 5: Cement consumption and axial compressive strength in relation to distribution coefficient

\section{CONCLUSIONS}

After applying the packing model and performing the experiments it is possible to conclude:

- For mortar consistency test, distribution coefficients lower than 0.3 produced more fluid and homogeneous mortars, whereas distribution coefficients greater than 0.3 led to drier and less homogeneous mortars, evidencing the need of evaluating the influence of a different compaction energy on the analysis of the packing index.

- The results obtained for higher specific mass and lower absorption values were found for mortar with distribution coefficient of 0.3 . It is possible that the compaction energy used in this work was not sufficient to locate all the particles in the specimen in the best way, especially for mixture designs with larger distribution coefficients, such as 0.5 and 0.6 .

- It is possible to achieve a reduction in cement consumption in the mixtures produced with distribution coefficients between 0.1 and 0.3 , with an increased axial compressive strength, reduced absorption and increased specific mass. Only by changing the volumetric quantity of the components, it could be achieved a reduction in cement consumption of approximately $32 \%$ be achieved while at the same time it could be achieved an increase in axial compressive strength of approximately 59\%, together with a reduction in absorption and an increase in the specimen specific mass. However, there is a significant decrease in mortar workability.

- The increased packing between aggregate particles is one of the main reasons for reducing cement consumption and absorption and increasing the compressive strength of the produced mortar.

- Thus, it can be concluded that the use of Funk and Dinger Particle Packing Model with the incorporation of cement as part of the "dry arrangement" facilitates its dosing in cementitious materials and, using different distribution coefficients of the same model, facilitates the desired workability.

\section{ACKNOWLEDGMENTS}

The authors would like to thank the Federal Technological University of Paraná for making laboratories and equipment available, to Cement Itambé for the supply of cement used in the research and also to the laboratory technician João Marcos Valezi for his collaboration and commitment in the laboratory work.

\section{BIBLIOGRAPHY}

[1] NBR. Associação Brasileira de Normas Técnicas. NBR 15575 - Edificações habitacionais: desempenho: parte 1: Requisitos gerais. 2013. 
[2] TUTIKIAN, B.F, HELENE, P. "Durabilidade e Vida Útil das Estruturas de Concreto". In: Geraldo C. Isaia (Org.), Concreto: Ciência e Tecnologia, v. 12, 2011.

[3] DAMINELI, B.L., PILEGGI, R.G., JHON, V.M. "Influência do empacotamento e dispersão de partículas no consumo de cimento de concretos", Revista IBRACON de Estruturas e Materiais, v. 10, n. 5, pp. 9981024, 2017.

[4] OLIVEIRA, C.O, MACIEL, G.F., CASTRO, A.L., BARBOSA, M.P., CAMPOS, R.S. "Impacto do conceito de empacotamento de partículas na dosagem de concretos de alto desempenho", Revista Matéria, v.23, n.3, 2018.

[5] DE LARRARD, F. "Concrete optimization with regard to packing density and rheology". In: $3^{\circ}$ Rilem: International Symposium on Rheology of Cement Suspensions Such as Fresh Concrete, França, 2009.

[6] WONG, H.H.C., KWAN, A.K.H. "Rheology of Cement Paste: Role of Excess Water to Solid Surface Area Ratio". Journal of Materials in Civil Engineering, pp. 189-197, 2008.

[7] OLIVEIRA, I.R., STUDART, A.R., PILEGGI, R.G., PANDOLFELLI, V.C. Dispersão e Empacotamento de Partículas: princípios e aplicações em processamento cerâmico. Ed. Fazendo Arte, S. Paulo, ISBN 8586425-15-X, p. 224, 2000

[8] FENNIS, S.A.A.M., WALRAVEN, J.C., DEN UIJL, J.A. "Defined-performance design of ecological concrete". Materials and Structures 46, pp. 639-650, 2013.

[9] CASTRO, A.L., PANDOLFELLI, V.C. "Revisão: Conceitos de dispersão e empacotamento de partículas para a produção de concretos especiais aplicados na construção civil". Cerâmica, v. 55, pp. 18-32, 2009.

[10] ORTEGA, F.S., PILEGGI, R.G., SEPULVEDA, P., et al., "Influência dos modelos de Alfred e de Andreasen sobre a microestrutura e densidade a verde de compactos cerâmicos obtidos por colagem ou prensagem". Cerâmica, v. 43, pp. 283-284, 1997.

[11] SILVA, A.P.; SEGADÃES, A.M.; DEVEZAS, T.C. "Aplicação de métodos estatísticos na otimização da densidade de empacotamento de distribuições de pós de alumina". Cerâmica, v. 50, pp. 345-354, 2004.

[12] BROUWERS, H.J.H.; RADIX, H.J. "Self-compacting concrete: the role of the particle size distribution". In: First International Symposium on Design Performance and use of self-consolidating Concrete-SCC, pp. 26-28, China, 2005.

[13] BONADIA, P., STUDART, A.R., PILEGGI, R.G., PANDOLFELLI, V. “Aplicação do conceito de distância de separação interagregado (MPT) a concretos refratários de alta alumina". Cerâmica, v.45 n. 291, 1999.

[14] HÜSKEN, G., BROUWERS, H.J.H. "A new mix design concept for earth-moist concrete: A theoretical and experimental study". Cement and Concrete Research 38, pp. 1246-1259, 2008.

[15] BLEECK, T.H. "Particle packing; an effective approach to optimized design of ultra high strength and self compacting concretes", Final Thesis Report, University of New South Wales at the Australian Defence Force Academy, pp. 17, 2011.

[16] BROUWERS, H.J.H.; RADIX, H.J., "Self-Compacting Concrete: Theoretical and experimental study", Cement and Concrete Research, v. 35, p.2116-2136, 2005.

[17] HUNGER, M.; BROUWERS, H.J.H. "Development of self-compacting eco-concrete". In: International Conference on Building Materials, p. 2-0189-2-0198, 2006.

[18] WANG, X., WANGB, K., TAYLOR, P., MORCOUS, G. Assessing particle packing based selfconsolidating concrete mix design method. Construction and Building Materials 70, pp. 439-452, 2014.

[19] AGUIAR, G. "Estudo de argamassas com agregados reciclados contaminados por gesso de construção". Dissertação (Mestrado) - Escola Politécnica da Universidade de São Paulo, 2004.

[20] ASSOCIAÇÃO BRASILEIRA DE NORMAS TÉCNICAS. NBR NM 52: agregado miúdo - determinação da massa específica e massa específica aparente. Rio de Janeiro. 2009.

[21] ASSOCIAÇÃO BRASILEIRA DE NORMAS TÉCNICAS. NBR NM 248: agregados - determinação da composição granulométrica. Rio de Janeiro. 2003.

[22] ASSOCIAÇÃO BRASILEIRA DE NORMAS TÉCNICAS. NBR NM 46: agregados - determinação do material fino que passa através da peneira 75 um, por lavagem. Rio de Janeiro. 2003.

[23] FENNIS, S.A.A.M.; WALRAVEN, J.C. "Using particle packing technology for sustainable concrete mixture design”, HERON, Delft University of Technology, the Netherlands, v. 57, N $.2 / 73$, p. 30, 2012. 
[24] FLATT, R.J., BOWEN, P. "Electrostatic repulsion between particles in cement suspensions: domain of validity of linearized Poisson-Boltzmann equation for nonideal electrolytes", Cement Concrete, v. 6, p. 781$791,2003$.

[25] PEDROSO, B., TERTUlinO, B., PULIDO, A. "Influência do Fator Água/Cimento para a Resistência do Concreto". In: Anais do VII CONCCEPAR: Congresso Científico da Região Centro-Ocidental do Paraná / Centro Universitário Integrado de Campo Mourão. - Campo Mourão, PR: Centro Universitário Integrado de Campo Mourão, 2016.

[26] ASSOCIAÇÃO BRASILEIRA DE NORMAS TÉCNICAS. NBR 7215: cimento Portland: determinação da resistência à compressão. Rio de Janeiro, 1996.

[27] METHA, P.K., MONTEIRO, P.J.M. “Concreto: estrutura, propriedades e materiais”. 3. ed. São Paulo: IBRACON, 2008.

[28] ASSOCIAÇÃO BRASILEIRA DE NORMAS TÉCNICAS. NBR 13276 (2002): argamassa para assentamento e revestimento de paredes e tetos - Preparo da mistura e determinação do índice de consistência. Rio de Janeiro, 2002.

[29] ASSOCIAÇÃO BRASILEIRA DE NORMAS TÉCNICAS. NBR 9778 (1987): Argamassa e concreto endurecidos - Determinação da absorção de água por imersão - Índice de vazios e massa específica. Rio de Janeiro, 1987.

[30] YOUSUF, S., SANCHEZ, L.F.M., SHAMMEH, S.A. "The use of particle packing models (PPMs) to design structural low cement concrete as an alternative for construction industry", Journal of Building Engineering 25, 100815, 2019.

[31] KWAN, A.K.H., FUNG, W.W.S., WONG, H.H.C. "Water film thickness, flowability and rheology of cement-sand mortar", Advances in Cement Research 22, №. 1, pp. 3-14, 2010.

[32] RIZWAN, S.A., AHMAD, S., BIER, T.A. Application of Packing Concepts to High Performance SelfConsolidating Mortar (SCM) Systems. American Concrete Institute, ACI Special Publication, 2012.

[33] CHU, S.H. "Effect of paste volume on fresh and hardened properties of concrete", Construction and Building Materials 218, pp. 284-294, 2019.

[34] LI, J., CHEN, Y., WAN, C. “A mix-design method for lightweight aggregate self-compactingconcrete based on packing and mortar film thickness theories", Construction and Building Materials 157, pp. 621-634, 2017.

\section{ORCID}

Aline Hermann

Géssica Katalyne Bilcati

Isabela Ames

Ana Gabriella Chekalski da Silva

Daniel Dal Agnol Grossman

Thayna Brena Alves Fausto https://orcid.org/0000-0003-0517-9372

https://orcid.org/0000-0002-5733-1332

https://orcid.org/0000-0002-7662-4309

https://orcid.org/0000-0002-4190-5848

https://orcid.org/0000-0002-8228-8188

https://orcid.org/0000-0003-2711-5468 